\section{Unanticipated difficult airway in male hypogonadism}

\section{Pasupuleti Hemalatha, Bathanpalli Aparna, Aloka Samantaray, Mangu H. Rao}

Difficulty in endotracheal intubation (ETI) is not very uncommon in patients with endocrine abnormality such as dwarfism ${ }^{[1,2]}$ and acromegaly. ${ }^{[3]}$ However, a difficult airway in a case of hypogonadism with no obvious body deformity is very much unanticipated and also scarcely reported in Indian literature. ${ }^{[4]}$ Here, we present a case of an unanticipated difficult intubation in a young boy with hypogonadism posted for an elective surgery.

An 18-year-old boy of height/weight $26.5 \mathrm{~kg} / 136 \mathrm{~cm}$ $\left(<3^{\text {rd }}\right.$ percentile) presented with chief complaints of headache and vomiting. Further examination showed left superior quadrant hemianopia and absent secondary sexual characters. Airway examination showed Mallampatti Grade II (MPG-II). Hormonal assay showed decreased levels of gonadotrophin releasing hormone. Computed tomography (CT) and magnetic resonance imaging (MRI) showed craniopharyngioma with mass effect on third ventricle. The patient was posted for excision of the tumour. After induction of general anaesthesia, ETI was tried with an age appropriate sized (8.0 mm ID) cuffed oral endotracheal tube (ETT). However, to our surprise the ETT could not be passed below the vocal cords, further attempts to pass 7.5 and $6.5 \mathrm{~mm}$ ID ETT also failed and finally a $6.0 \mathrm{~mm}$ ETT was passed snugly (Cormack-Lehane Grade I). As there was no air leak cuff was not inflated. At the end of the surgery, neuromuscular paralysis was reversed with neostigmine, glycopyrrolate and extubated. Immediately after extubation patient developed inspiratory stridor, which was treated with $100 \%$ oxygen, jaw thrust, adrenaline nebulization and subsided within $10 \mathrm{~min}$.

Department of Anaesthesiology and Critical Care, Sri Venkateswara Institute of Medical Sciences, Tirupati, Andhra Pradesh, India

Address for correspondence:

Dr. Pasupuleti Hemalatha, Department of Anaesthesiology and Critical Care, Sri Venkateswara Institute of Medical Sciences, SVIMS University, Tirupati - 517 507, Andhra Pradesh, India.

E-mail: madhugastro@gmail.com
We encountered intubation difficulty when age appropriate $\mathrm{ETT}^{[5]}$ was used in an otherwise easy airway (MPG-II). The patient's airway was re-evaluated in the post-operative period. The CT scan showed tracheal diameter at cricoid ring was $11 \mathrm{~mm} \times 10 \mathrm{~mm}$ [Figure 1] and at the thyroid cartilage was $12 \mathrm{~mm} \times 9 \mathrm{~mm}$ (anteroposterior/transverse) [Figure 2]. MRI could not give us any information as it was confined to cranium.

We tried intubating the patient with $8.0 \mathrm{~mm}$ (outer diameter [OD] $10.7 \mathrm{~mm}$ ), $7.5 \mathrm{~mm}$ (OD $10.0 \mathrm{~mm}$ ), $6.5 \mathrm{~mm}$ (OD $8.7 \mathrm{~mm}$ ) ETT but finally, could pass a $6.0 \mathrm{~mm}$ ID ETT (OD $8.2 \mathrm{~mm}$ ). In all these attempts, there was difficulty in negotiating the ETT below the vocal cords. This difficulty may be due to the small cricoid diameter compared to tracheal diameter at the level of thyroid.

Before puberty larynx of boys and girls are equally small, ${ }^{[6]}$ but with attainment of puberty larynx grows in both sexes, more in boys, causing twice increase in the length of the vocal cords. By puberty vocal cords reach their adult size and clear sexual dimorphism is evident with significantly larger linear height, weight and prominent thyroid prominence in male larynx which precedes the development of facial hair by several months.

Beckford et al. ${ }^{[7]}$ in their animal experiment demonstrated androgens play a major role in development of male larynx. Similarly, high-affinity androgen receptors have been demonstrated in human larynx. ${ }^{[8]}$

Our patient has not attained puberty due to hypogonadism and his larynx resembled a 10-12 year old child's pre-pubertal larynx. Moreover, repeated attempts at tracheal intubation have resulted in sub-glottis oedema and hence we could pass only $6.0 \mathrm{~mm}$ ETT. The sub-glottis

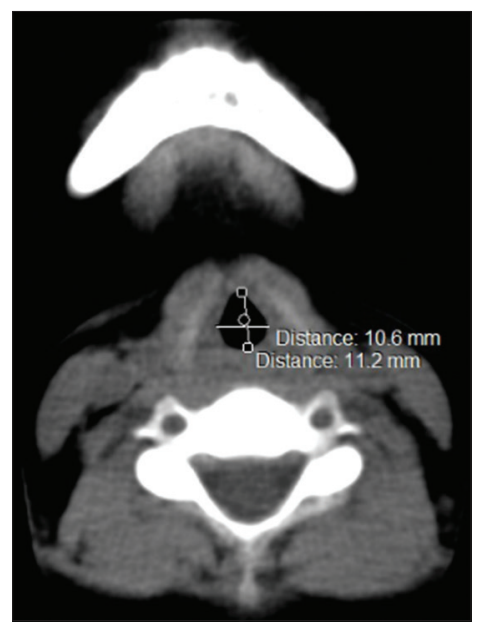

Figure 1: Computed tomographic scan showing the laryngeal measurements at the level of thyroid cartilage cross section 


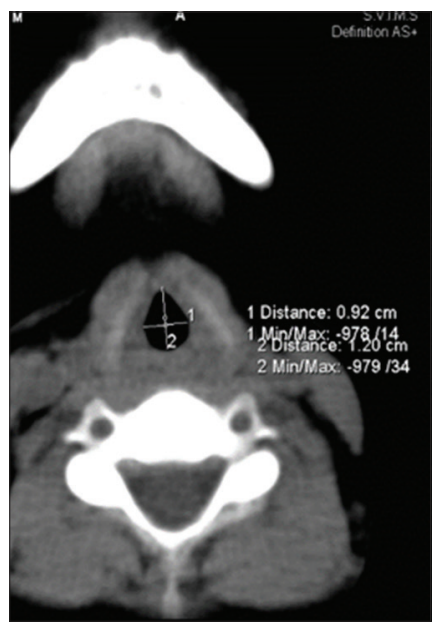

Figure 2: Computed tomographic scan showing the laryngeal measurements at the level of cricoid cross section

oedema could also have been the possible cause for post extubation stridor. We strongly feel that, a closer and detailed look at the imaging study before anaesthetizing the patients could have averted the problems of repeat tracheal intubation and its complications.

We opine that in male hypogonadism difficult airway should be anticipated. CT and MRI sections should also involve the larynx along with the cranium for information on the airway to prevent morbidity and mortality.

\section{Acknowledgments}

We acknowledge Department of Neurosurgery, Endocrinology and Radiology, Sri Venkateswara Institute of Medical Sciences, for their valuable support in providing clinical material and suggestions during manuscript preparation.

\section{Financial support and sponsorship}

Nil.

\section{Conflicts of interest}

There are no conflicts of interest.

\section{REFERENCES}

1. Berkowitz ID, Raja SN, Bender KS, Kopits SE. Dwarfs: Pathophysiology and anesthetic implications. Anesthesiology 1990;73:739-59.

2. Herlich A. Complications from securing the difficult airway. Int Anesthesiol Clin 1997;35:13-30.

3. Kitahata LM. Airway difficulties associated with anaesthesia in acromegaly. Three case reports. $\mathrm{Br} \mathrm{J}$ Anaesth 1971;43:1187-90.

4. Manikandan S, Neema PK, Rathod RC. Airway problems caused by hypogonadism in male patients undergoing neurosurgery. Anesth Analg 2005;101:1812-5.

5. Teenage Growth and Development: 11 to 14 Years. Available from: http://www.PaloAltoMedicalFoundation/pamf.org. [Last retrieved on 2013 Dec 09].

6. "The Structure of the Larynx". Encyclopaedia Britannica. Available from: http://www.britannica.com/EBchecked/ topic/559032/speech/68966/The-structure-of-the-larynx. [Last retrieved on 2009 Feb 20].

7. Beckford NS, Rood SR, Schaid D, Schanbacher B. Androgen stimulation and laryngeal development. Ann Otol Rhinol Laryngol 1985;94(6 Pt 1):634-40.

8. SaezS,SakaiF.Androgen receptors in human pharyngo-laryngeal mucosa and pharyngo-laryngeal epithelioma. J Steroid Biochem 1976;7:919-21.

This is an open access article distributed under the terms of the Creative Commons Attribution-NonCommercial-ShareAlike 3.0 License, which allows others to remix, tweak, and build upon the work non-commercially, as long as the author is credited and the new creations are licensed under the identical terms.

\begin{tabular}{|l|l|}
\hline \multicolumn{2}{|c|}{ Access this article online } \\
\hline Quick Response Code: & Website: \\
\hline & www.jnaccjournal.org \\
\hline & \\
\hline
\end{tabular}

How to cite this article: Hemalatha $P$, Aparna B, Samantaray A, Rao MH. Unanticipated difficult airway in male hypogonadism. J Neuroanaesthesiol Crit Care 2017;4:181-2. 